\title{
Enhanced supply of methionine or arginine alters mechanistic target of rapamycin signaling proteins, messenger RNA, and microRNA abundance in heat-stressed bovine mammary epithelial cells in vitro
}

\author{
A. A. K. Salama, ${ }^{1}$ M. Duque,${ }^{2}$ L. Wang, ${ }^{3}$ K. Shahzad, ${ }^{4}$ M. Olivera, ${ }^{2}$ and J. J. Loor ${ }^{4 *}$ \\ ${ }^{1}$ Group of Research in Ruminants (G2R), Department of Animal and Food Sciences, Universitat Autònoma de Barcelona, Bellaterra 08193, Spain \\ ${ }^{2}$ Grupo de Investigación Biogénesis, Facultad de Ciencias Agrarias, Universidad de Antioquia, Carrera 75 \# 65-87, Medellín, Colombia \\ ${ }^{3}$ Department of Animal Science, Southwest University, Rongchang, Chongqing 402460, China \\ ${ }^{4}$ Mammalian NutriPhysioGenomics, Department of Animal Sciences and Division of Nutritional Sciences, University of Illinois, Urbana 61801
}

\section{ABSTRACT}

Heat stress (HS) causes reductions in milk production, but it is unclear whether this effect is due to reduced number or functional capacity (or both) of mammary cells. Methionine supplementation improves milk protein, whereas Arg is taken up in excess by mammary cells to produce energy and nonessential AA that can be incorporated into milk protein. To evaluate molecular mechanisms by which mammary functional capacity is affected by HS and Met or Arg, mammary alveolar (MAC-T) cells were incubated at thermal-neutral $\left(37^{\circ} \mathrm{C}\right)$ or $\mathrm{HS}\left(42^{\circ} \mathrm{C}\right)$ temperatures. Treatments were optimal AA profiles (control; Lys:Met $=2.9: 1.0$; Lys: Arg $=2.1: 1.0)$, control plus Met (Lys:Met $=2.5: 1.0)$, or control plus Arg (Lys:Arg = 1.0:1.0). After incubation for $6 \mathrm{~h}$, cells were harvested and RNA and protein were extracted for quantitative real-time PCR and Western blotting. Protein abundance of mechanistic target of rapamycin (MTOR), eukaryotic initiation factor 2a, serine-threonine protein kinase (AKT), 4E binding protein 1 (EIF4EBP1), and phosphorylated EIF4EBP1 was lower during HS. The lower phosphorylated EIF4EBP1 with HS would diminish translation initiation and reduce protein synthesis. Both Met and Arg had no effect on MTOR proteins, but the phosphorylated EIF4EBP1 decreased by AA, especially Arg. Additionally, Met but not Arg decreased the abundance of phosphorylated eukaryotic elongation factor 2 , which could be positive for protein synthesis. Although HS upregulated the heat shock protein $H S P A 1 A$, the apoptotic gene $B A X$, and the translation inhibitor EIF $4 E B P 1$, the mRNA abundance of PPARG, FASN, ACACA (lipogenesis),

Received June 15, 2018.

Accepted November 13, 2018.

*Corresponding author: jloor@illinois.edu and BCL2L1 (antiapoptotic) decreased. Greater supply of Met or Arg reversed most of the effects of HS occurring at the mRNA level and upregulated the abundance of HSPA1A. In addition, compared with the control, supply of Met or Arg upregulated genes related to transcription and translation (MAPK1, MTOR, SREBF1, RPS6KB1, JAK2), insulin signaling (AKT2, IRS1), AA transport (SLC1A5, SLC7A1), and cell proliferation (MKI67). Upregulation of microRNA related to cell growth arrest and apoptosis (miR-34a, miR-92a, miR-99, and miR-184) and oxidative stress (miR-141 and miR-200a) coupled with downregulation of fat synthesis-related microRNA (miR-27ab and miR-221) were detected with HS. Results suggest that HS has a direct negative effect on synthesis of protein and fat, mediated in part by coordinated changes in mRNA, microRNA, and protein abundance of key networks. The positive responses with Met and Arg raise the possibility that supplementation with these AA during HS might have a positive effect on mammary metabolism. Key words: essential amino acid, lactation, mammary function, nutrition

\section{INTRODUCTION}

Compared with thermal-neutral (TN) conditions, heat stress (HS) reduces milk yield and contents of fat and protein in milk (Hamzaoui et al., 2013; Salama et al., 2016). Dairy animals under HS experience reduced $\mathrm{N}$ intake because of decreasing DMI, $\mathrm{N}$ losses in sweat (Joshi et al., 1968), and reduced rumen microbial protein synthesis (Hyder et al., 2017). This may cause shortages in the EAA needed for milk protein synthesis and, consequently, a reduction in milk protein. Whether the lack of EAA during HS affects milk protein synthesis in mammary cells is not well known. High temperatures can inhibit the growth of cells and result in alterations in structural proteins, membrane permeability (increase in intracellular $\mathrm{Na}^{+}, \mathrm{H}^{+}$, and 
$\mathrm{Ca}^{2+}$ concentrations), and metabolism (net reduction in cellular ATP; Collier et al., 2006; Mu et al., 2014).

Supplementation of Met significantly improves milk protein percentage and yield in dairy cows (Zhou et al., 2017; Batistel et al., 2018; Lean et al., 2018). Furthermore, enhancing the supply of Met to cultured bovine mammary cells consistently upregulates mRNA abundance of CSN1S1, CSN1S2, CSN2, CSN3, LALBA, JAK2, STAT5, and MTOR, which reflects an increase in protein synthesis (Nan et al., 2014; Dong et al., 2018). In the context of HS, enhancing Met supply in vitro reduced apoptosis and necrosis, decreased lipid peroxidation, and increased superoxide dismutase, catalase, and glutathione peroxidase enzymatic activity, leading to an overall cytoprotective effect during hyperthermia (Mu et al., 2014; Han et al., 2015).

The mammary gland extracts branched-chain AA, Arg, and Lys in excess and uses them to produce energy or to synthesize NEAA (Lapierre et al., 2012). Specifically, Arg is extracted in excess and transformed to urea and ornithine (O'Quinn et al., 2002). Ornithine is the precursor of proline and several NEAA. Furthermore, Arg by means of nitric oxide synthase is converted to nitric oxide (O'Quinn et al., 2002) that controls blood flow (Lacasse et al., 1996). Reduced mammary blood flow under HS (Lough et al., 1990) could be a cause of the decrease in milk components because it can determine the amount of nutrients arriving in the mammary for milk synthesis. Recently, Wang et al. $(2014,2017)$ proposed an important role for Arg in the transcriptional regulation of casein genes and mechanistic target of rapamycin (MTOR)-related genes in bovine mammary epithelial cells.

Several previous studies have independently evaluated the role of EAA on mRNA abundance and MTOR signaling either in MAC-T and primary bovine mammary cells (Appuhamy et al., 2011; Nan et al., 2014; Dong et al., 2018) or in primary mammary cells exposed to HS at $42^{\circ} \mathrm{C}$ (Collier et al., 2006; Kapila et al., 2013). However, little is known about the response of MTOR signaling when mammary cells are simultaneously exposed to HS and supplemented with AA.

MicroRNA (miRNA) are small noncoding RNA that regulate gene expression at the posttranscriptional level. Evidence indicates that several miRNA play an important role in lactation initiation and milk fat and protein syntheses in dairy cows (Do et al., 2017). Furthermore, external factors that affect milk yield and quality also alter miRNA expression in the mammary gland. For instance, forage source in the diet (alfalfa, corn stover, or rice straw) was associated with different profiles of miRNA expression in the mammary gland of dairy cows (Wang et al., 2016a). As indicated above,
HS reduces the content of fat and protein in milk, and the published data cited above indicate that miRNA may play an important role in the transcriptional regulation of genes during HS. Little is known about the role of miRNA in HS mammary cells.

Our hypothesis was that HS would impair cellular and molecular processes in mammary cells and that the supplementation with Met and Arg could alleviate the negative effects of HS on cell functions. Thus, the specific objective of the present experiment was to use MAC-T cells (an immortalized, nonsecretory bovine cell line) to study the effects of supplementation with Arg and Met on the expression of genes, proteins related to MTOR, and miRNA expression under TN and HS conditions. These type of data are essential to increase our systems understanding of the regulation of milk protein synthesis (Loor et al., 2013).

\section{MATERIALS AND METHODS}

\section{Cell Culture and Treatments}

Unless otherwise indicated, all reagents and chemicals were purchased from Sigma-Aldrich (St. Louis, $\mathrm{MO})$. Frozen bovine MAC-T cells were recovered and cultured in $75-\mathrm{cm}^{2}$ flasks at $37^{\circ} \mathrm{C}$ in a humidified atmosphere with $5 \% \mathrm{CO}_{2}$. Subcultures were repeated until enough cells were obtained for the experiment. The basal medium used for cell culture was minimum essential medium with Earle's balanced salts (GE Healthcare Life Sciences, Logan, UT) supplemented with $10 \%$ fetal bovine serum, $5 \mathrm{mg} / \mathrm{L}$ insulin, $1 \mathrm{mg} / \mathrm{L}$ hydrocortisone, $5 \mathrm{mg} / \mathrm{L}$ transferrin, $5 \mu M$ ascorbic acid, $5 \mathrm{~m} M$ sodium acetate, $100 \mathrm{U} / \mathrm{mL}$ penicillin, $100 \mu \mathrm{g} / \mathrm{mL}$ streptomycin, $0.25 \mu \mathrm{g} / \mathrm{mL}$ antimycotic, $1 \mathrm{mg} / \mathrm{L}$ progesterone, $0.05 \%$ lactalbumin, and $0.05 \%$-lactose. When 80 to $90 \%$ confluency was reached, cells were collected by trypsincell strep and seeded in wells (for each well, 20,000 cells $\times 9.5 \mathrm{~cm}^{2}=190,200$ cells $)$.

The protocol for cell culture used is similar to that reported previously in similar studies (Peterson et al., 2004; Dong et al., 2018). Cells were allowed to grow in wells until the confluency was 80 to $90 \%$. Then, $3 \mathrm{~mL}$ of lactogenic medium was added, and plates were incubated overnight at $37^{\circ} \mathrm{C}$. The lactogenic medium was similar to the basal medium except that high-glucose Dulbecco's modified Eagle's medium (Hyclone, GE Healthcare Life Sciences) was used to replace minimum essential medium with Earle's balanced salts, and BSA $(1 \mathrm{~g} / \mathrm{L})$ and prolactin $(2.5 \mathrm{mg} / \mathrm{L})$ were supplemented. Cells were washed 3 times with PBS, and $3 \mathrm{~mL}$ of the lactogenic medium (Table 1) containing 3 AA treatments was added. Cultures were performed for $6 \mathrm{~h}$ at 
$37^{\circ} \mathrm{C}(\mathrm{TN})$ or $42^{\circ} \mathrm{C}(\mathrm{HS})$. The 6 -h culture time was based on similar work by Collier et al. (2006) in which the mRNA abundance of heat shock protein (HSP)-70 was dramatically stimulated between 1 and $2 \mathrm{~h}$ and appeared to peak within $4 \mathrm{~h}$ of exposing mammary cells to $42^{\circ} \mathrm{C}$. In the same study, 162 genes had altered mRNA abundance by $4 \mathrm{~h}$ of exposure to $42^{\circ} \mathrm{C}$. The AA treatments were control with an ideal AA profile (Dong et al., 2018), control plus $10 \mu \mathrm{g} / \mathrm{mL}$ Met, or control plus $84 \mu \mathrm{g} / \mathrm{mL}$ Arg. Because the mammary gland uses Arg in excess, we decided to double the concentration of $\operatorname{Arg}$ (from 84 to $168 \mu \mathrm{g} / \mathrm{mL}$ ) to achieve a maximum response. The level of Met used was based on previous work from our laboratory dealing with MAC-T cells (Dong et al., 2018) or primary neutrophils (Abdelmegeid et al., 2017) to increase the supply of Met beyond the considered ideal ratio of 2.9:1 of Lys:Met. This resulted in 6 treatment combinations: (1) TN and control, (2) TN and control plus $10 \mu \mathrm{g} / \mathrm{mL}$ Met, (3) TN and control plus $84 \mu \mathrm{g} / \mathrm{mL} \mathrm{Arg,} \mathrm{(4)} \mathrm{HS} \mathrm{and} \mathrm{control,} \mathrm{(5)}$ HS and control plus $10 \mu \mathrm{g} / \mathrm{mL}$ Met, and (6) HS and control plus $84 \mu \mathrm{g} / \mathrm{mL}$ Arg. After the $6 \mathrm{~h}$ of incubation, cells were harvested by adding $1 \mathrm{~mL}$ of QIAzol reagent (Invitrogen, Carlsbad, CA) in each well for 5 min. Cells were then collected and stored at $-80^{\circ} \mathrm{C}$ until RNA extraction and Western blot analysis.

\section{RNA Extraction and Quantitative Real-Time PCR}

Total RNA from the cells was extracted using ice-cold TRIzol reagent (Invitrogen). The RNA was purified to

Table 1. Amino acid composition $(\mu \mathrm{g} / \mathrm{mL})$ of the experimental lactogenic media ${ }^{1}$ used for culture $(6 \mathrm{~h})$ of the bovine mammary epithelial cell line MAC-T

\begin{tabular}{lccc}
\hline & \multicolumn{3}{c}{ Treatment $^{2}$} \\
\cline { 2 - 4 } AA & Control & Met & Arg \\
\hline Composition & & & \\
Lys & 175 & 175 & 175 \\
Met & 60 & 70 & 60 \\
Thr & 97 & 97 & 97 \\
Phe & 92 & 92 & 92 \\
His & 74 & 74 & 74 \\
Val & 142 & 142 & 142 \\
Ile & 121 & 121 & 121 \\
Leu & 206 & 206 & 206 \\
Arg & 84 & 84 & 168 \\
Trp & 16 & 16 & 16 \\
Ratio & & & \\
Lys:Met & $2.9: 1.0$ & $2.5: 1.0$ & $2.9: 1.0$ \\
Lys:Arg & $2.1: 1.0$ & $2.1: 1.0$ & $1.0: 1.0$ \\
\hline
\end{tabular}

${ }^{1}$ Custom high-glucose Dulbecco's modified Eagle's medium (Hyclone; GE Healthcare Life Sciences, Logan, UT) devoid of all EAA was used. ${ }^{2}$ Control = Lys:Met 2.9:1.0; Met = control plus Met (Lys:Met = 2.5:1.0); Arg = control plus Arg (Lys:Arg = 1.0:1.0). remove genomic DNA with DNase using RNeasy Mini Kit columns (Qiagen, Valencia, CA). Concentrations of RNA were measured with a NanoDrop ND-1000 spectrophotometer (Thermo Scientific, Wilmington, DE). The RNA integrity was assessed using an Agilent 2100 Bioanalyzer (Agilent Technologies, Santa Clara, CA). The RNA integrity number values ranged from 8.6 to 9.7. A portion of the total RNA was diluted to $100 \mathrm{ng} /$ $\mu \mathrm{L}$ using RNase-free water before cDNA synthesis.

The cDNA was synthesized using $100 \mathrm{ng}$ of total RNA, $1 \mu \mathrm{L}$ of Random Primers (Roche, Basel, Switzerland), and $9 \mu \mathrm{L}$ of RNase-free water. The mixture was incubated at $65^{\circ} \mathrm{C}$ for 5 min in an Eppendorf Mastercycler Gradient (Fisher Scientific, Waltham, MA). A total of $9 \mu \mathrm{L}$ of Master Mix comprising $4 \mu \mathrm{L}$ of $5 \times$ First-Strand Buffer (Fermentas, Pittsburgh, PA), $1 \mu \mathrm{L}$ of oligo dT18, $2 \mu \mathrm{L}$ of $10 \mathrm{~m} M \mathrm{dNTP}$ mix (Invitrogen), $0.25 \mu \mathrm{L}$ of Reverse Aid RT (Fermentas), $0.125 \mu \mathrm{L}$ of RNase Inhibitor (Fermentas), and $1.625 \mu \mathrm{L}$ of RNasefree water was added. The reaction was performed using the following temperature program: $25^{\circ} \mathrm{C}$ for $5 \mathrm{~min}$, $42^{\circ} \mathrm{C}$ for $60 \mathrm{~min}$, and $70^{\circ} \mathrm{C}$ for $5 \mathrm{~min}$. The cDNA was then diluted 1:4 with RNase-free water.

The quantitative real-time PCR (qPCR) was performed in a MicroAmp Optical 384-well reaction plate (Applied Biosystems, Foster City, CA) using $4 \mu \mathrm{L}$ of diluted cDNA combined with $6 \mu \mathrm{L}$ of mixture. The mixture comprised $5 \mu \mathrm{L}$ of $1 \times$ SYBR Green Master Mix (Quanta, Gaithersburg, MD), $0.4 \mu \mathrm{L}$ each of 10 $\mu M$ forward and reverse primers, and $0.2 \mu \mathrm{L}$ of RNasefree water. The target genes included HSP family A member 1A ( $\boldsymbol{H S P A 1 A}$ ), de novo fatty acids synthesis enzymes (acetyl-CoA carboxylase $\alpha, \boldsymbol{A C A C A}$; fatty acid synthase, $\boldsymbol{F} \boldsymbol{A} \boldsymbol{S N}$ ), AA transporters (solute carrier family 7 member $1, \boldsymbol{S L} \boldsymbol{C} \boldsymbol{7} \boldsymbol{A} \mathbf{1}$; solute carrier family 1 member 5, SLC1A5), milk protein gene transcription (signal transducer and activator of transcription $5 \mathrm{~B}$,

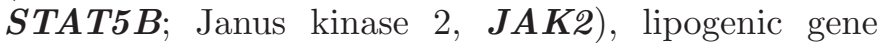
transcription (sterol regulatory element binding transcription factor 1, SREBF1; peroxisome proliferator-

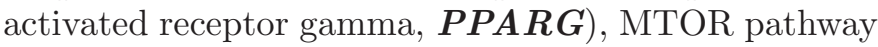
components (MTOR; eukaryotic translation initiation factor $4 \mathrm{E}$ binding protein $1, \boldsymbol{E I F} 4 \boldsymbol{E B P} 1$; ribosomal

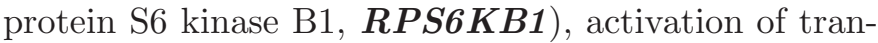
scription and translation (mitogen-activated protein kinase 1, $\boldsymbol{M A P K 1}$ ), insulin signaling [insulin receptor substrate 1, IRS1; serine-threonine protein kinase $(\boldsymbol{A} \boldsymbol{K} \boldsymbol{T})$ serine/threonine kinase 1 and 2, AKT1, AKT2], and mammary cell turnover (marker of proliferation Ki67, MKI6 7; BCL2-like 1, BCL2L1; BCL2 associated $\mathrm{X}$, apoptosis regulator, $\boldsymbol{B} \boldsymbol{A} \boldsymbol{X})$. The geometric mean of $G A D P H$, ubiquitously expressed prefoldin-like chaperone $(\boldsymbol{U X} \boldsymbol{T})$, and ribosomal protein S9 (RPS9) was 
used to normalize mRNA abundance. Each sample and a 6-point relative standard curve plus the nontemplate control were run in triplicate. All qPCR reactions were performed in an ABI Prism 7900 HT SDS instrument (Applied Biosystems) at $95^{\circ} \mathrm{C}$ for $5 \mathrm{~min}$, followed by 40 cycles at $95^{\circ} \mathrm{C}$ for $1 \mathrm{~s}$ and $60^{\circ} \mathrm{C}$ for $30 \mathrm{~s}$. The presence of a single PCR product was verified by the dissociation protocol using incremental temperatures to $95^{\circ} \mathrm{C}$ for 15 $\mathrm{s}, 65^{\circ} \mathrm{C}$ for $15 \mathrm{~s}$, and $95^{\circ} \mathrm{C}$ for $15 \mathrm{~s}$. Data were analyzed using the standard curve with 7900 HT Sequence Detection Systems Software (version 2.4; Applied Biosystems). Methods for primer design and validation as well as primer sequences were as reported previously (Bionaz and Loor, 2011).

\section{MicroRNA Extraction and qPCR}

The miRNA were extracted from cells according to the manufacturer's protocol (mir-Vana miRNA Isolation Kit, AM1561; Applied Biosystems). Ribonucleic acid $(10 \mu \mathrm{g})$ was polyadenylated using Poly(A) polymerase according to the manufacturer's instructions (NCode miRNA, First Strand cDNA Module, no. 45-6612; Invitrogen). Complementary DNA was made as follows: $10 \mu \mathrm{g}$ of polyadenylated RNA was reverse transcribed using Superscript II reverse transcriptase (Invitrogen) with $2.5 \mu \mathrm{g}$ of random hexamers and 500 ng of oligo (dT) adapter primer (Invitrogen) according to the manufacturer's instructions.

The reactions were performed in triplicate as follows: $5 \mu \mathrm{L}$ of cDNA was mixed with 5 pmol of both the forward and reverse primers in a final volume of 12.5 $\mu \mathrm{L}$ and mixed with $12.5 \mu \mathrm{L}$ of $2 \times$ Power SYBR Green PCR Master Mix (no. 4367659; Applied Biosystems). All reactions were run using 2 amplification protocols: $20 \mathrm{~s}$ at $94^{\circ} \mathrm{C}, 30 \mathrm{~s}$ at $59^{\circ} \mathrm{C}$, and $20 \mathrm{~s}$ at $72^{\circ} \mathrm{C}$ for 40 cycles. The same conditions were performed on an equal amount of RNase-free water as a negative control. Primer sequences are reported in Supplemental Table S1 (https://doi.org/10.3168/jds.2018-15219).

Real-time quantitative PCR with SYBR Green I (Power SYBR Green, PCR Master Mix, no. 4367659; Applied Biosystems) was performed in an ABI Prism 7900 HT SDS instrument (Applied Biosystems), and the data were calculated with 7900 HT Sequence Detection Systems software (version 2.2.1; Applied Biosystems). The geometric mean of 5S (catalog no. AM30302; Applied Biosystems) and U6 was used to normalize the expression of target miRNA.

\section{Western Blotting}

Total protein from each of the 3 replicates per treatment was extracted using tissue protein extraction reagent (catalog no. 78510; Thermo Scientific), which included inhibitor Cocktail $(100 \times$, catalog no. 78442; Thermo Scientific). The concentrations of total protein were determined with the BCA assay kit (catalog no. 23227; Thermo Scientific). Protein samples were boiled at $100^{\circ} \mathrm{C}$ for $10 \mathrm{~min} ; 80 \mu \mathrm{g}$ of total protein per lane was resolved by SDS-PAGE and then transferred to polyvinylidene difluoride membrane (catalog no. 1620261; Bio-Rad, Hercules, CA) by using the semidry transfer assembly (Bio-Rad). Membranes were blocked in Trisbuffered saline-Tween (TBST; 50 m $M$ Tris, pH 7.6; 150 $\mathrm{m} M \mathrm{NaCl}$; and $0.1 \%$ Tween 20 ), which contained $5 \%$ (wt/vol) nonfat milk, for $2 \mathrm{~h}$ at room temperature with gentle agitation. The membranes were then incubated in TBST with $5 \%$ nonfat milk containing antibodies to MTOR, phosphorylated (p)-MTOR, RPS6KB1, p-RPS6KB1, EIF4EBP1, p-EIF4EBP1, eukaryotic translation initiation factor 2A (EIF2A), p-EIF2A, eukaryotic elongation factor 2 (EEF2), p-EEF2, AKT and p-AKT (catalog no. 2972A, 2971S, 9202S, 9234S, 9452S, 9459S, 5324P, 3398S, 2332S, 2331S, 9272S, and 9272S, respectively; Cell Signaling Technology, Danvers, MA) with gentle agitation at $4^{\circ} \mathrm{C}$ overnight. After incubating with primary antibody, the membranes were washed and incubated with horseradish peroxidaseconjugated secondary antibodies (catalog no. ab6721; Abcam, Cambridge, UK) in TBST for $1 \mathrm{~h}$ at room temperature. The membranes were washed and then incubated with ECL reagent (catalog no. 170-5060; Bio-Rad). Tubulin (catalog no. 2144S; Cell Signaling Technology) and GAPDH (catalog no. ab22555; Abcam) were the internal controls. The images were captured using ChemiDOC MP (Bio-Rad). The intensities of the bands were measured with Image-Pro Plus 6.0 software (Media Cybernetics Inc., Rockville, MD).

\section{Statistical Analyses and Calculations}

Western blot data with nonnormal distribution and all mRNA abundance data were $\log _{2}$ transformed to obtain a normal distribution before statistical analysis. Statistical analysis was performed using the MIXED model in SAS (version 9.3; SAS Institute Inc., Cary, $\mathrm{NC}$ ). The qPCR data were normalized using the geometric mean of the 3 internal control genes (GADPH, $U X T$, and RPS9) for mRNA and both $5 \mathrm{~S}$ and $\mathrm{U} 6$ for miRNA before $\log _{2}$ transformation. The statistical model included the main effects of AA supplementation (control, Met, and Arg), temperature (TN vs. HS), and their interaction as fixed effects. The Kenward-Roger statement was used for computing the denominator degrees of freedom. Treatment means were compared using the PDIFF statement in SAS after correction us- 
ing Tukey's test. Significance was declared at a PDIFF Tukey-adjusted $P<0.05$.

\section{RESULTS AND DISCUSSION}

Core body temperatures above $41^{\circ} \mathrm{C}$ have been reported in heat-stressed dairy cows and goats (Baumgard and Rhoads, 2013; Salama et al., 2014). Furthermore, Collier et al. (2006), Mu et al. (2014), and Han et al. (2015) stressed bovine mammary cells at $42^{\circ} \mathrm{C}$. Thus, our choice of HS temperature was in accordance with previous work of a similar nature. The fact that mRNA abundance of the HSP gene was significantly increased (discussed below) in cells undergoing HS indicated that thermotolerance was not lost by $6 \mathrm{~h}$ of treatment at $42^{\circ} \mathrm{C}$. Overall, previous and present data underscore the suitability of the chosen temperature and incubation time to address the specific hypothesis and objectives of the study.

\section{HS and AA Responses on mRNA and Protein Abundance}

A dramatic upregulation $(P<0.001)$ of HSPA1A (70-kDa HSP) abundance was observed with HS (Table 2 ), confirming data from a previous study with bovine mammary epithelial cells incubated at $42^{\circ} \mathrm{C}$ for $30 \mathrm{~min}$
(Han et al., 2015). In the study of Han et al. (2015), protein abundance of HSPA1A also increased with HS. The protein encoded by this gene plays a heightened role in cell cryoprotection and is frequently used as a biomarker of cellular stress (Sonna et al., 2002). Levels of HSP increase dramatically, but transiently, in cells exposed to an insult as a mechanism to bind to unfolded or misfolded proteins and help restore their native conformation (Feder and Hofmann, 1999).

The HSPA1A was also upregulated $(P<0.001)$ by both Met and Arg, especially under HS conditions (Table 2). The upregulation of HSPA1A when Met and Arg were supplemented suggests that under HS conditions an increase in the supply of Met and Arg (and probably other AA) to mammary cells could be channeled for synthesis of extra proteins that serve a protective role. Such role has been reported for Met as it can increase HSPA1A expression during HS, oxidative stress, and other stress states in cells or tissues (Han et al., 2015).

With regard to AA transporters, we detected an upregulation $(P<0.001)$ of the abundance of $S L C 1 A 5$ (MTOR related) and $S L C 7 A 1$ (MTOR unrelated) with HS (Table 2). Assuming that the synthesis rate of cytoprotective proteins increases during HS, an increase in the use of AA to synthetize more HSP appears logical. This condition would result in the upregulation of AA transporters to meet the increased requirements

Table 2. Effects of incubating mammary cells in thermal-neutral $\left(37^{\circ} \mathrm{C}\right)$ or heat stress $\left(42^{\circ} \mathrm{C}\right)$ conditions $(6 \mathrm{~h})$ with an ideal ratio of Lys to Met (Lys:Met 2.9:1; control) or treatments containing Lys:Met at 2.5:1 (Met) or Lys:Arg at 1.0:1.0 (Arg) on mRNA abundance (log scale) of genes associated with heat stress, mechanistic target of rapamycin pathway, lipogenesis, and cell turnover

\begin{tabular}{|c|c|c|c|c|c|c|c|c|c|c|}
\hline \multirow[b]{2}{*}{ Gene } & \multicolumn{3}{|c|}{ Thermal neutral } & \multicolumn{3}{|c|}{ Heat stress } & \multirow[b]{2}{*}{$\mathrm{SEM}^{1}$} & \multicolumn{3}{|c|}{$P$-value ${ }^{2}$} \\
\hline & Control & Met & Arg & Control & Met & Arg & & Temp & $\mathrm{AA}$ & Temp $\times \mathrm{AA}$ \\
\hline HSP $70 A 1 A$ & $0.12^{\mathrm{d}}$ & $0.30^{\mathrm{c}}$ & $0.27^{\mathrm{c}}$ & $1.16^{\mathrm{b}}$ & $18.21^{\mathrm{a}}$ & $6.82^{\mathrm{a}}$ & 8.03 & 0.001 & 0.001 & 0.001 \\
\hline MTOR & $0.78^{\mathrm{c}}$ & $0.99^{\mathrm{b}}$ & $0.81^{\mathrm{bc}}$ & $0.63^{\mathrm{c}}$ & $1.44^{\mathrm{a}}$ & $0.88^{\mathrm{abc}}$ & 0.30 & 0.350 & 0.013 & 0.018 \\
\hline$E I F 4 E B P 1$ & $0.85^{\mathrm{c}}$ & $0.66^{\mathrm{d}}$ & $1.31^{\mathrm{b}}$ & $1.62^{\mathrm{ab}}$ & $0.65^{\mathrm{cd}}$ & $2.47^{\mathrm{a}}$ & 0.87 & 0.001 & 0.008 & 0.031 \\
\hline RPS6KB1 & $1.15^{\mathrm{y}}$ & $1.82^{\mathrm{x}}$ & $1.62^{\mathrm{xy}}$ & $1.37^{\mathrm{y}}$ & $3.36^{\mathrm{x}}$ & $2.23^{\mathrm{xy}}$ & 1.23 & 0.012 & 0.075 & 0.446 \\
\hline$I R S 1$ & $0.90^{\mathrm{b}}$ & $0.89^{\mathrm{b}}$ & $0.90^{\mathrm{b}}$ & $0.87^{\mathrm{b}}$ & $0.98^{\mathrm{a}}$ & $0.88^{\mathrm{b}}$ & 0.02 & 0.501 & 0.052 & 0.017 \\
\hline$A K T 1$ & $1.44^{\mathrm{c}}$ & $2.68^{\mathrm{b}}$ & $7.53^{\mathrm{a}}$ & $0.54^{\mathrm{d}}$ & $1.51^{\mathrm{bcd}}$ & $12.9^{\mathrm{a}}$ & 8.25 & 0.114 & 0.001 & 0.014 \\
\hline$A K T 2$ & $0.22^{y}$ & $0.42^{\mathrm{x}}$ & $0.35^{\mathrm{xy}}$ & $0.69^{\mathrm{y}}$ & $3.12^{\mathrm{x}}$ & $1.89^{\mathrm{xy}}$ & 1.40 & 0.001 & 0.012 & 0.145 \\
\hline$S L C 1 A 5$ & 0.57 & 0.73 & 1.26 & 2.96 & 3.72 & 8.36 & 4.50 & 0.001 & 0.124 & 0.773 \\
\hline SLC7A1 & $0.97^{\mathrm{y}}$ & $1.12^{\mathrm{xy}}$ & $1.50^{\mathrm{x}}$ & 1.25 & 1.58 & 2.35 & 0.71 & 0.001 & 0.101 & 0.727 \\
\hline$J A K 2$ & $0.62^{\mathrm{c}}$ & $1.60^{\mathrm{b}}$ & $2.12^{\mathrm{b}}$ & $0.39^{\mathrm{c}}$ & $2.52^{\mathrm{ab}}$ & $4.67^{\mathrm{a}}$ & 2.27 & 0.098 & 0.001 & 0.005 \\
\hline STAT5B & 0.81 & 0.76 & 0.97 & 1.68 & 1.17 & 1.74 & 0.42 & 0.001 & 0.278 & 0.261 \\
\hline$M A P K 1$ & $0.83^{y}$ & $1.53^{\mathrm{x}}$ & $1.61^{\mathrm{x}}$ & $0.64^{\mathrm{y}}$ & $1.65^{\mathrm{x}}$ & $1.80^{\mathrm{x}}$ & 0.80 & 0.864 & 0.010 & 0.498 \\
\hline$P P A R G$ & $0.90^{\mathrm{c}}$ & $1.30^{\mathrm{a}}$ & $1.28^{\mathrm{a}}$ & $0.94^{\mathrm{bc}}$ & $1.13^{\mathrm{ab}}$ & $0.84^{\mathrm{c}}$ & 0.09 & 0.008 & 0.002 & 0.019 \\
\hline SREBF1 & $0.71^{y}$ & $1.30^{\mathrm{x}}$ & $1.47^{\mathrm{x}}$ & $0.46^{\mathrm{y}}$ & $1.50^{\mathrm{x}}$ & $1.94^{\mathrm{x}}$ & 1.03 & 0.968 & 0.008 & 0.176 \\
\hline$A C A C A$ & 1.21 & 1.30 & 1.31 & 0.70 & 0.67 & 0.62 & 1.75 & 0.001 & 0.833 & 0.336 \\
\hline$F A S N$ & $1.05^{\mathrm{c}}$ & $2.19^{\mathrm{a}}$ & $1.86^{\mathrm{ab}}$ & $0.18^{\mathrm{d}}$ & $0.96^{\mathrm{bc}}$ & $0.63^{\mathrm{c}}$ & 0.42 & 0.001 & 0.001 & 0.042 \\
\hline MKI67 & $1.23^{\mathrm{z}}$ & $3.32^{y}$ & $8.70^{\mathrm{x}}$ & $0.83^{y}$ & $3.01^{\mathrm{y}}$ & $18.4^{\mathrm{x}}$ & 14.1 & 0.719 & 0.001 & 0.150 \\
\hline BCL2L1 & $0.61^{\mathrm{b}}$ & $3.63^{\mathrm{a}}$ & $3.62^{\mathrm{a}}$ & $0.01^{\mathrm{c}}$ & $5.50^{\mathrm{a}}$ & $4.48^{\mathrm{a}}$ & 3.52 & 0.001 & 0.001 & 0.001 \\
\hline$B A X$ & $0.38^{\mathrm{c}}$ & $0.36^{\mathrm{c}}$ & $0.36^{\mathrm{c}}$ & $0.46^{\mathrm{b}}$ & $0.49^{\mathrm{a}}$ & $0.46^{\mathrm{b}}$ & 0.01 & 0.001 & 0.287 & 0.034 \\
\hline
\end{tabular}

\footnotetext{
${ }^{\mathrm{a}-\mathrm{d}}$ Means across temperature and AA treatment when temperature $\times$ AA is significant differ $(P<0.05)$.

${ }^{\mathrm{x}-\mathrm{z}}$ Means within each temperature condition when temperature $\times$ AA is not significant differ $(P<0.05)$ between AA treatments.

${ }^{1}$ Largest SEM for temperature $\times$ AA.

${ }^{2}$ Temp $=$ temperature.
} 
of producing cytoprotective proteins. Pirkkala et al. (2001) revealed that HS increases production of proteins necessary for restoring normal cellular function and directing cellular remodeling (structural proteins, cell-cycle control proteins, and proteins involved in proand antiapoptotic pathways).

Heat stress did not affect $(P>0.05)$ the abundance of IRS1 or AKT1, but upregulated $(P<0.05)$ AKT2 (Table 2). In contrast, Met supplementation upregulated $(P<0.05) I R S 1$ and AKT2 abundance, whereas Arg only upregulated $(P<0.05)$ abundance of $A K T 1$. Bionaz and Loor (2011) revealed that one of the mechanisms in the mammary gland to enhance insulin (or IGF-1) sensitivity as lactation progresses is the upregulation of the IRS1-PDK-AKT signaling pathway. In the present study, the fact that Met supplementation had an effect on IRS1 and AKT2 during HS suggests that it can potentially enhance insulin sensitivity under stress conditions.

Abundance of STAT5B $(P<0.001)$, a component of the JAK-STAT signaling pathway, was upregulated with HS. Additionally, JAK2 abundance was upregulated $(P<0.001)$ with Met and Arg supplementation, but no effect was observed on STAT5B (Table 2). A role for STAT5 in controlling milk protein gene expression through the Jak2-Stat5 signaling pathway has been reported (Bionaz and Loor, 2011). It is possible that these changes in the abundance of STAT5 and JAK are related to the increase in synthesis of cytoprotective proteins during HS.

Although HS had no effect on MAPK1 abundance, the supplementation with Met or Arg increased its abundance (Table 2). Evidence indicates that MAPK1 could induce protein synthesis in bovine mammary cells through the phosphorylation of MTOR and STAT5 (Lu et al., 2012). Taking into account that increasing the supplementation of Lys led to greater protein content of MAPK1 in bovine mammary cells (Lu et al., 2012), the present data suggest that Met and Arg could elicit a similar effect.

There was a temperature and AA interaction $(P<$ 0.05) effect on HSP70A1A, MTOR, EIF4BP1, IRS1, $A K T 1$, and JAK2 abundance (Table 2). This interaction resulted from the fact that Met or Arg supplementation had more marked effect during HS than during TN conditions.

Heat stress downregulated $(P<0.01)$ the abundance of PPARG without affecting SREBF1 (Table 2). Furthermore, HS downregulated $(P<0.01) A C A C A$ and $F A S N$. Although the current study is in vitro, the obtained results agree with the fact that HS consistently decreases the concentration of de novo-synthesized FA in milk of dairy cows (Hammami et al., 2015).
Supplementation of Met upregulated $(P<0.01)$ the abundance of both PPARG and SREBF1, whereas Arg upregulated only $S R E B F 1$. Additionally, Arg and Met supplementation did not affect $A C A C A$ but did enhance $(P<0.001)$ the abundance of $F A S N$. A significant interaction $(P<0.05)$ between temperature and AA supplementation was detected for PPARG and FASN abundance (Table 2). These data suggest the existence of a mechanism in which AA supplementation (especially Met) can directly or indirectly affect milk fat synthesis. It is known that $S R E B F 1$ plays important roles in milk fat depression induced by greater availability of trans-10, cis-12 CLA to mammary cells (Ma and Corl, 2012). Additionally, in vitro data demonstrated that various lipogenic genes (ACACA, FASN, and $S C D)$ are direct targets of PPARG in goat mammary cells (Shi et al., 2013). Thus, the negative effect of HS on PPARG expression might explain at least in part the decrease in fat synthesis capacity of mammary cells in dairy animals exposed to hyperthermia.

The expression of MKI67, BCL2L1, and BAX was used to evaluate proliferation, antiapoptotic, and proapoptotic responses in mammary epithelial cells, respectively. Exposure to HS did not seem to affect $(P$ $>0.05)$ proliferation but downregulated $(P<0.001)$ antiapoptotic and upregulated proapoptotic signals (Table 2). A previous study reported that incubation of bovine mammary cells at $42^{\circ} \mathrm{C}$ for 30 min decreased proliferation and increased apoptosis (Han et al., 2015). Because HS reduces antioxidant capacity and increases free radicals at the systemic and cellular levels (Liu et al., 2010), such a mechanism could have accounted for the observed responses in BCL2L1 and BAX. Additionally, HS induces several abnormalities in cell function, including the inhibition of protein synthesis, changes in protein folding and function, and changes in metabolism and membrane fluidity, all of which reduce proliferation and increase apoptosis in cultured bovine mammary cells (Collier et al., 2006).

The supplementation with Arg and Met upregulated $(P<0.01)$ the abundance of MKI67 (mammary proliferation) and BCL2L1 (antiapoptotic; Table 2). Similarly, Han et al. (2015) reported that, by reducing the oxidative stress, increasing supply of Met markedly decreased the mortality of cultured bovine mammary cells that suffered hyperthermia. In fact, increased Met supply in heat-stressed mammary cells decreased malondialdehyde and nitric oxide concentrations along with nitric oxide synthase (all indicators of oxidative stress; Han et al., 2015). Additionally, Met had a positive effect on superoxide dismutase, catalase, and glutathione peroxidase enzymatic activities (antioxidant enzymes). Thus, Met supply seems to be effective at providing 
some protection against cellular damage, in large part through its antioxidant action (Osorio et al., 2014).

One of the primary uses of Arg by the mammary gland is for conversion to ornithine and nitric oxide (O'Quinn et al., 2002). The metabolic end products of the conversion of Arg to ornithine are putrescine, spermidine, and spermine (Wu et al., 2009). Putrescine has positive effects on cell proliferation (Chen et al., 2015), which might explain the positive effect of Arg on MKI67 expression (Table 2). In fact, inhibition of the Arg-ornithine pathway (via inhibition of arginase) reduced mammary cell proliferation (Wang et al., 2017). The significant temperature and AA interaction detected for BCL2L1 and BAX abundance (Table 2) was due to the fact that AA supplementation upregulated mRNA abundance to a greater extent under HS than under TN conditions.

Exposure to HS did not alter $(P>0.05)$ mRNA abundance of $A K T 1$ but upregulated $A K T 2(P<0.001$; Table 2). However, total and phosphorylated AKT protein abundances were reduced $(P<0.001)$ by HS (Table 3). Exposure to HS also decreased $(P<0.001)$ total protein abundance of MTOR (Table 3) without affecting its mRNA abundance (Table 2) or phosphorylation (Table 3). Despite the upregulation in mRNA abundance of EIF4EBP1 with HS (0.46 vs. $-0.14 ; P<$ 0.001 ), its total protein abundance was lower (1.19 vs. $1.57 ; P<0.001)$. Hence, the inhibitory effect of HS on mammary protein synthesis typically observed in vivo could be explained by the hypophosphorylation of EIF4EBP1 detected in the current study (1.68 vs. $2.73 ; P$ $<0.001)$. Furthermore, the fact that HS did not change MTOR phosphorylation (Table 3) suggests that the effect on EIF4EBP1 was independent of MTOR. The lower ratio of phosphorylated to total EIF4BP1 protein in control cells during HS (Figure 1) could be related to the lower milk protein content usually observed in dairy animals under HS conditions.

Temperature had no effect $(P>0.05)$ on the phosphorylation of RPS6KB1 or RPS6 (Table 3). With regards to other important components of the protein synthesis network, namely the integrated stress network, HS compared with TN tended to increase $(P$ $=0.10)$ the phosphorylation of EIF2A. Greater phosphorylation of EIF2A is associated with lower milk protein synthesis (Baird and Wek, 2012). With regard to translation elongation, exposure to HS decreased $(P$ $<0.05$ ) total and phosphorylated protein abundance of EEF2, but the phosphorylation ratio was not affected by HS (6.25 vs. 5.13 for TN and HS, respectively; SEM $=1.16, P=0.382)$. Along with the response observed for EIF4EBP1 (Tables 2 and 3), the decrease in EEF2 protein abundance with HS (Table 3 ) seems to be part of the mechanism responsible for the lower milk protein content usually observed in animals exposed to high ambient temperatures.

Supplementation with Met and Arg increased $(P$ $<0.001)$ the abundance of total AKT, whereas phos-

Table 3. Effects of incubating mammary cells in thermal-neutral $\left(37^{\circ} \mathrm{C}\right)$ or heat stress $\left(42^{\circ} \mathrm{C}\right)$ conditions $(6 \mathrm{~h})$ with an ideal ratio of Lys to Met (Lys:Met 2.9:1; control) or treatments containing Lys:Met at 2.5:1 (Met) or Lys:Arg at 1.0:1.0 (Arg) on total and phosphorylated (p) protein abundance (arbitrary units) of components of the insulin and mechanistic target of rapamycin signaling pathways

\begin{tabular}{|c|c|c|c|c|c|c|c|c|c|c|}
\hline \multirow[b]{2}{*}{ Protein $^{1}$} & \multicolumn{3}{|c|}{ Thermal neutral } & \multicolumn{3}{|c|}{ Heat stress } & \multirow[b]{2}{*}{$\mathrm{SEM}^{2}$} & \multicolumn{3}{|c|}{$P$-value ${ }^{3}$} \\
\hline & Control & Met & Arg & Control & Met & Arg & & Temp & $\mathrm{AA}$ & Temp $\times$ AA \\
\hline Total MTOR & $0.67^{\mathrm{b}}$ & $0.87^{\mathrm{a}}$ & $0.73^{\mathrm{ab}}$ & $0.53^{\mathrm{c}}$ & $0.36^{\mathrm{d}}$ & $0.44^{\mathrm{cd}}$ & 0.05 & 0.001 & 0.841 & 0.005 \\
\hline p-MTOR & $0.22^{\mathrm{b}}$ & $0.20^{\mathrm{b}}$ & $0.51^{\mathrm{a}}$ & $0.22^{\mathrm{ab}}$ & $0.24^{\mathrm{ab}}$ & $0.08^{\mathrm{b}}$ & 0.23 & 0.105 & 0.929 & 0.032 \\
\hline Total EIF4EBP1 & $0.82^{\mathrm{c}}$ & $0.95^{\mathrm{c}}$ & $2.95^{\mathrm{a}}$ & $0.87^{\mathrm{c}}$ & $0.71^{\mathrm{c}}$ & $1.99^{\mathrm{b}}$ & 0.10 & 0.001 & 0.001 & 0.001 \\
\hline p-EIF4EBP1 & $4.31^{\mathrm{a}}$ & $2.98^{\mathrm{b}}$ & $0.91^{\mathrm{d}}$ & $2.07^{\mathrm{c}}$ & $2.47^{\mathrm{c}}$ & $0.50^{\mathrm{d}}$ & 0.17 & 0.001 & 0.001 & 0.001 \\
\hline Total RPS6KB1 & $0.88^{\mathrm{y}}$ & $2.63^{\mathrm{x}}$ & $0.61^{\mathrm{y}}$ & $1.00^{\mathrm{y}}$ & $2.63^{\mathrm{x}}$ & $0.74^{\mathrm{y}}$ & 0.12 & 0.405 & 0.001 & 0.823 \\
\hline p-RPS6KB1 & $0.27^{\mathrm{b}}$ & $0.45^{\mathrm{a}}$ & $0.40^{\mathrm{ab}}$ & $0.44^{\mathrm{ab}}$ & $0.05^{\mathrm{b}}$ & $0.32^{\mathrm{ab}}$ & 0.27 & 0.858 & 0.237 & 0.046 \\
\hline Total RPS6 & 13.5 & 12.6 & 8.96 & 6.07 & 10.8 & 13.5 & 9.06 & 0.623 & 0.951 & 0.282 \\
\hline p-RPS6 & 30.9 & 24.0 & 65.0 & 43.1 & 19.9 & 72.6 & 27.0 & 0.580 & 0.213 & 0.765 \\
\hline Total EEF2 & $1.18^{\text {de }}$ & $2.72^{\mathrm{b}}$ & $3.47^{\mathrm{a}}$ & $1.91^{\mathrm{c}}$ & $0.79^{\mathrm{e}}$ & $1.54^{\mathrm{cd}}$ & 0.23 & 0.001 & 0.001 & 0.001 \\
\hline p-EEF2 & $12.5^{\mathrm{b}}$ & $3.90^{\mathrm{d}}$ & $22.2^{\mathrm{a}}$ & $8.32^{\mathrm{c}}$ & $4.81^{\mathrm{cd}}$ & $5.20^{\mathrm{cd}}$ & 1.56 & 0.001 & 0.001 & 0.001 \\
\hline Total AKT & $4.13^{\mathrm{c}}$ & $11.8^{\mathrm{a}}$ & $7.38^{\mathrm{b}}$ & $2.18^{\mathrm{cd}}$ & $1.25^{\mathrm{d}}$ & $3.05^{\mathrm{cd}}$ & 0.88 & 0.001 & 0.002 & 0.001 \\
\hline p-AKT & $1.27^{\mathrm{y}}$ & $1.38^{\mathrm{y}}$ & $2.27^{\mathrm{x}}$ & $0.60^{\mathrm{y}}$ & $0.75^{\mathrm{y}}$ & $1.48^{\mathrm{x}}$ & 0.17 & 0.001 & 0.001 & 0.884 \\
\hline Total EIF2A & $7.17^{\mathrm{y}}$ & $21.9^{\mathrm{x}}$ & $1.19^{\mathrm{y}}$ & $7.69^{y}$ & $24.9^{\mathrm{x}}$ & $-2.74^{\mathrm{y}}$ & 8.00 & 0.961 & 0.005 & 0.538 \\
\hline p-EIF2A & 0.61 & 0.61 & 1.69 & 1.88 & 0.83 & 1.56 & 0.84 & 0.102 & 0.476 & 0.104 \\
\hline
\end{tabular}

${ }^{\mathrm{a} e \mathrm{e}}$ Means across temperature and AA treatment when temperature $\times$ AA is significant differ $(P<0.05)$.

${ }^{\mathrm{x}, \mathrm{y}}$ Means within each temperature condition when temperature $\times$ AA is not significant differ $(P<0.05)$ between AA treatments.

${ }^{1} \mathrm{MTOR}=$ mechanistic target of rapamycin; EIF4EBP1 = eukaryotic translation initiation factor 4E binding protein 1 ; RPS6KB1 = ribosomal protein S6 kinase B1; RPS6 = ribosomal protein S6; EEF2 = eukaryotic elongation factor 2; AKT = serine-threonine protein kinase; EIF2A = eukaryotic translation initiation factor $2 \mathrm{~A}$.

${ }^{2}$ Largest SEM for temperature $\times$ AA.

${ }^{3}$ Temp $=$ temperature. 

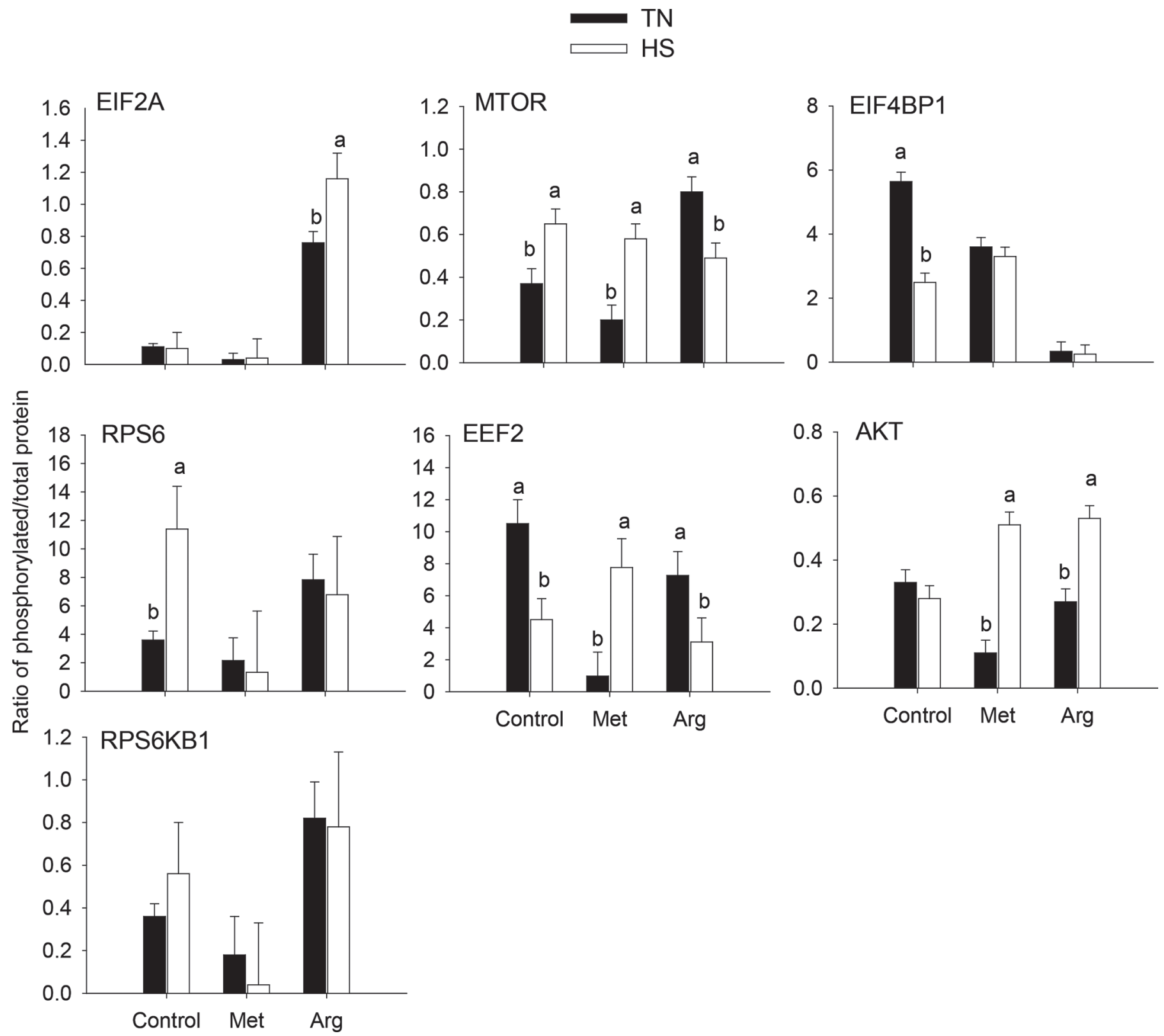

Figure 1. Effects of incubating mammary cells in thermal neutral $\left(\mathrm{TN}, 37^{\circ} \mathrm{C}\right)$ or heat stress $\left(\mathrm{HS}, 42^{\circ} \mathrm{C}\right)$ conditions with the ideal $\mathrm{AA}$ ratio (Lys:Met 2.9:1; control) or treatments containing Lys:Met at 2.5:1 (Met) or Lys:Arg 1.0:1.0 (Arg) on the ratio of phosphorylated protein to total protein (arbitrary units) of components of the insulin and mechanistic target of rapamycin (MTOR) pathways. Means with different letters (a, b) differ $(P<0.05$; temperature $\times$ AA effect $)$. Panels show ratio of phosphorylated $(\mathrm{p})$ protein to total protein (e.g., p-EIF2A/total EIF2A) for eukaryotic initiation factor 2a (EIF2A), MTOR, ribosomal protein S6 (RPS6), eukaryotic elongation factor 2 (EEF2), serine-threonine protein kinase (AKT), and ribosomal protein S6 kinase B1 (RPS6KB1).

phorylated AKT increased $(P<0.01)$ only with Arg (Table 3). The kinase AKT plays an important role in the regulation of MTOR activity by sensing signals related to cell differentiation, proliferation, and apoptosis (Reddi et al., 2016). Despite the change in AKT abundance, protein abundance of MTOR or phosphorylated MTOR did not differ in response to Met or Arg supplementation (Table 3). This result was unexpected because (at least in nonruminants) the phosphorylation status of AKT and MTOR is often consistent. However, our results agree with Dong et al. (2018), who detected that Met supplementation to achieve a Lys:Met ratio of 2.5 (from 2:9:1 in the control) in MAC-T cells decreased MTOR but increased AKT phosphorylation. Thus, at least in vitro, a mismatch between AKT and MTOR phosphorylation in response to Arg supplemen- 
Table 4. Effects of incubating mammary cells in thermal-neutral $\left(37^{\circ} \mathrm{C}\right)$ or heat stress $\left(42^{\circ} \mathrm{C}\right)$ conditions with an ideal AA ratio $($ Lys:Met $2.9: 1$; control) or treatments containing Lys:Met at 2.5:1 (Met) or Lys:Arg at 1.0:1.0 (Arg) on abundance (log scale) of microRNA

\begin{tabular}{|c|c|c|c|c|c|c|c|c|c|c|}
\hline \multirow[b]{2}{*}{ MicroRNA } & \multicolumn{3}{|c|}{ Thermal neutral } & \multicolumn{3}{|c|}{ Heat stress } & \multirow[b]{2}{*}{$\mathrm{SEM}^{1}$} & \multicolumn{3}{|c|}{$P$-value ${ }^{2}$} \\
\hline & Con & Met & Arg & Con & Met & Arg & & Temp & $\mathrm{AA}$ & Temp $\times$ AA \\
\hline miR-26a & $1.47^{\mathrm{x}}$ & $0.63^{\mathrm{y}}$ & $1.09^{\mathrm{xy}}$ & $2.32^{\mathrm{x}}$ & $0.61^{y}$ & $1.75^{\mathrm{xy}}$ & 0.97 & 0.111 & 0.022 & 0.434 \\
\hline miR-27ab & 0.77 & 0.81 & 0.93 & 1.04 & 1.23 & 1.07 & 0.22 & 0.001 & 0.669 & 0.318 \\
\hline miR-34a & 1.24 & 0.87 & 0.99 & 2.04 & 1.38 & 0.96 & 0.59 & 0.043 & 0.279 & 0.275 \\
\hline miR-92a & 1.41 & 0.86 & 1.22 & 2.92 & 1.26 & 1.46 & 1.08 & 0.024 & 0.209 & 0.488 \\
\hline miR-141 & $1.21^{\mathrm{b}}$ & $1.48^{\mathrm{b}}$ & $0.60^{\mathrm{c}}$ & $1.57^{\mathrm{b}}$ & $6.60^{\mathrm{a}}$ & $0.59^{\mathrm{bc}}$ & 3.60 & 0.007 & 0.024 & 0.011 \\
\hline miR-184 & 0.74 & 0.74 & 0.91 & 0.92 & 0.86 & 1.07 & 0.25 & 0.032 & 0.572 & 0.943 \\
\hline miR-200a & 1.00 & 0.67 & 0.76 & 1.35 & 1.04 & 0.98 & 0.32 & 0.004 & 0.260 & 0.776 \\
\hline miR-221 & 0.60 & 0.64 & 0.75 & 1.10 & 1.05 & 1.16 & 0.06 & 0.001 & 0.024 & 0.290 \\
\hline
\end{tabular}

${ }^{\mathrm{a}-\mathrm{c}}$ Means across temperature and AA treatment when temperature $\times \mathrm{AA}$ is significant differ $(P<0.05)$.

${ }^{\mathrm{x}, \mathrm{y}}$ Means within each temperature condition when temperature $\times \mathrm{AA}$ is not significant differ $(P<0.05)$ between AA treatments.

${ }^{1}$ Largest SEM for temperature $\times$ AA.

${ }^{2} \mathrm{Temp}=$ temperature.

tation could also occur. The exact reason for this type of response is unclear.

\section{HS and AA Responses on MicroRNA Abundance}

Heat stress upregulated $(P<0.05)$ the abundance of miR-34a, miR-92a, miR-99, and miR-184 by 42,62 , 113 , and $19 \%$, respectively (Table 4). Upregulation of miR-34a induced apoptosis in Hep2 cells (Wang et al., 2016b) and mammary cells (Jena, 2017) and inhibited cell proliferation (Wang et al., 2016b). Hermeking (2010) showed that several genes targeted by miR-34a are suppressed, resulting in growth arrest and greater levels of apoptosis, and Smith et al. (2015) reported that miR-92 inhibition exerts an oncogenic role within mammary cells by downregulating the expression of specific antiproliferative or proapoptotic genes. Furthermore, Hu et al. (2014) showed that overexpression of miR-99a reduces breast cancer cell viability by inducing accumulation of cells at the sub- $\mathrm{G}_{1}$ phase leading to apoptosis.

The activation of miR-184 also inhibits proliferation and self-renewal of triple negative breast cancer cell lines in vitro and delayed primary tumor formation and reduced metastatic burden in vivo (Phua et al., 2015). Together, these findings suggest that overexpression of miR-34a, miR-92a, miR-99, and miR-184 would lead to cell growth arrest, which agrees with the fact that the proapoptotic gene $B A X$ was upregulated with $\mathrm{HS}$ in the current study (Table 2).

Abundance of miR-141 and miR-200a was upregulated $(P<0.01)$ by HS (Table 4$)$. At least in nonruminants, miR-200a and miR-141 are thought to interact with the same target sites (Nagaoka et al., 2013) and both are overexpressed in tissues with high levels of oxidative stress (Magenta et al., 2017). Specifically, miR-200a regulates the Keap1/Nrf2 pathway in mammary epithelium, which is related to the oxidative stress (Eades et al., 2011). Thus, when miR-200a is upregulated, cellular oxidative stress is increased. Although we did not measure oxidative stress in the present study, HS has been shown to increase cell oxidative stress and the accumulation of free radicals and peroxides (Liu et al., 2010). Thus, we speculate that the overexpression of miR-200a during HS was related to cellular oxidative stress.

The abundance of miR-27ab and miR-221 during HS was upregulated $(P<0.001)$ by 32 and $67 \%$, respectively (Table 4). Tang et al. (2017) reported that the overexpression of miR-27a in bovine mammary cells significantly suppresses lipid droplet formation, decreases cellular triacylglycerol levels, and inhibits mRNA abundance of PPARG. In addition, Chu et al. (2018) reported that inhibition of miR-221 increased lipid content in mammary epithelial cells through elevation of the lipid synthesis enzyme FASN, whereas overexpression of miR-221 decreased mammary epithelial cell lipid content. In the current study, HS downregulated the abundance of FASN and PPARG (Table 2), which could have been mediated by the overexpression of miR-221 and miR-27ab, respectively.

Both Met and Arg supplementation downregulated ( $P$ $<0.05$ ) abundance of miR-23a. This miRNA has been shown to control abundance of genes related to milk fat synthesis (Zhang et al., 2014). Thus, we speculate that the positive effect of Met and Arg on the abundance of PPARG, SREBF1, and FASN (Table 2) could have been mediated by the change in abundance of miR-23a. 
Additionally, Met supplementation downregulated $(P$ $<0.05$ ) abundance of miR-26a. This miRNA represses cyclin D2 and cyclin E2, which play critical roles in the transition through the $\mathrm{G}_{1}-\mathrm{S}$ checkpoint; hence, it plays a role in cellular apoptosis (Kota et al., 2009). Thus, at least at the molecular level, the data suggest a positive effect of Met on reducing mammary cellular apoptosis.

Although Arg upregulated abundance of $S R E B F 1$ and FASN (Table 2), it also upregulated miR-221 (Table 4), which has a negative effect on fat synthesis (Chu et al., 2018). It is possible that the effect of Arg on inhibition of miR-23a overcomes the upregulation of miR-221, with the net result of enhancing milk fat synthesis. Furthermore, Met supplementation upregulated miR-141 during HS but not TN conditions, resulting in a significant interaction between temperature and AA (Table 4). Because miR-141 is a member of the miR-200 family that responds to increased levels of oxidative stress, its upregulation with Met during HS is unclear. In fact, Met protects against hyperthermiainduced oxidative stress in cultured bovine mammary epithelial cells (Han et al., 2015). Further research will help clarify the relationship between Met and miRNA in the mammary gland.

\section{CONCLUSIONS}

Heat stress causes changes at the molecular level in mammary cells. These changes are related to the synthesis of milk components and mammary cell turnover. The inhibitory effect of HS on milk protein synthesis could be due to the hypophosphorylation of EIF4EBP1, and it seems independent of the MTOR pathway. Heat stress negatively affects milk fat synthesis by downregulating de novo fatty acid synthesis genes through decreasing PPARG gene expression but not SREBF1. Methionine and Arg supplementation has a positive effect on milk synthesis by upregulating $F A S N$ and activating both PPARG and SREBF1. Additionally, HS did not affect mammary proliferation but did upregulate proapoptotic signals. On the other hand, Met and Arg supplementation upregulated mammary cell proliferation but did not affect apoptosis. Effects of HS and AA were related to changes in the expression of various miRNA controlling apoptosis, proliferation, oxidative stress, and fat synthesis. Additionally, findings raise the possibility that supplemental AA (especially Met) during HS might have a positive effect on mammary metabolism.

\section{ACKNOWLEDGMENTS}

A. A. K. Salama received a scholar fellowship from the Erasmus Mundus Program (Copenhagen, Den- mark), M. Duque received a training fellowship from Colciencias (Bogota, Colombia), and L. Wang received a postdoctoral fellowship from China Scholarship Council (Beijing).

\section{REFERENCES}

Abdelmegeid, M. K., M. Vailati-Riboni, A. Alharthi, F. Batistel, and J. J. Loor. 2017. Supplemental methionine, choline, or taurine alter in vitro gene network expression of polymorphonuclear leukocytes from neonatal Holstein calves. J. Dairy Sci. 100:3155-3165. https://doi.org/10.3168/jds.2016-12025.

Appuhamy, J. A., A. L. Bell, W. A. Nayananjalie, J. Escobar, and M. D. Hanigan. 2011. Essential amino acids regulate both initiation and elongation of mRNA translation independent of insulin in MAC-T cells and bovine mammary tissue slices. J. Nutr. 141:1209-1215. https://doi.org/10.3945/jn.110.136143.

Baird, T. D., and R. C. Wek. 2012. Eukaryotic initiation factor 2 phosphorylation and translational control in metabolism. Adv. Nutr. 3:307-321. https://doi.org/10.3945/an.112.002113.

Batistel, F., J. M. Arroyo, A. Bellingeri, L. Wang, B. Saremi, C. Parys, E. Trevisi, F. C. Cardoso, and J. J. Loor. 2017. Ethyl-cellulose rumen-protected methionine enhances performance during the periparturient period and early lactation in Holstein dairy cows. J. Dairy Sci. 100:7455-7467. https://doi.org/10.3168/jds.2017-12689.

Baumgard, L. H., and R. P. Rhoads Jr.. 2013. Effects of heat stress on postabsorptive metabolism and energetics. Annu. Rev. Anim. Biosci. 1:311-337. https://doi.org/10.1146/annurev-animal-031412 -103644 .

Bionaz, M., and J. J. Loor. 2011. Gene networks driving bovine mammary protein synthesis during the lactation cycle. Bioinform. Biol. Insights 5:83-98. https://doi.org/10.4137/BBI.S7003.

Chen, J. L., X. Bi, H. Zhang, F. Wang, Y. Wang, and Z. Guo. 2015. Putrescine promotes human marrow mesenchymal stem cells to differentiate along osteogenic pathway. Zhongguo Shi Yan Xue Ye Xue Za Zhi 23:809-813. https://doi.org/10.7534/j.issn.1009-2137 2015.03.040.

Chu, M., Y. Zhao, S. Yu, Y. Hao, P. Zhang, Y. Feng, H. Zhang, D. Ma, J. Liu, M. Cheng, L. Li, W. Shen, H. Cao, Q. Li, and L. Min. 2018. MicroRNA-221 may be involved in lipid metabolism in mammary epithelial cells. Int. J. Biochem. Cell Biol. 97:118-127. https://doi .org/10.1016/j.biocel.2018.02.014.

Collier, R. J., C. M. Stiening, B. C. Pollard, M. J. VanBaale, L. H. Baumgard, P. C. Gentry, and P. M. Coussens. 2006. Use of gene expression microarrays for evaluating environmental stress tolerance at the cellular level in cattle. J. Anim. Sci. 84(E. Suppl.):E1E13.

Do, D. N., R. Li, P. Dudemaine, and E. M. Ibeagha-Awemua. 2017. MicroRNA roles in signalling during lactation: An insight from differential expression, time course and pathway analyses of deep sequence data. Sci. Rep. 7:44605. https://doi.org/10.1038/ srep44605.

Dong, X., Z. Zhou, B. Saremi, A. Helmbrecht, Z. Wang, and J. J. Loor. 2018. Varying the ratio of Lys:Met while maintaining the ratios of Thr:Phe, Lys:Thr, Lys:His, and Lys:Val alters mammary cellular metabolites, mammalian target of rapamycin signaling, and gene transcription. J. Dairy Sci. 101:1708-1718. https://doi.org/ 10.3168/jds.2017-13351.

Eades, G., M. Yang, Y. Yao, Y. Zhang, and Q. Zhou. 2011. miR200a regulates Nrf2 activation by targeting keap1 mRNA in breast cancer cells. J. Biol. Chem. 286:40725-40733. https://doi.org/10 $.1074 / \mathrm{jbc} . \mathrm{M} 111.275495$.

Feder, M. E., and G. E. Hofmann. 1999. Heat shock proteins, molecular chaperones, and the stress response: Evolutionary and ecological physiology. Annu. Rev. Physiol. 61:243-282. https://doi.org/10 .1146/annurev.physiol.61.1.243.

Hammami, H., J. Vandenplas, M. L. Vanrobays, B. Rekik, C. Bastin, and N. Gengler. 2015. Genetic analysis of heat stress effects on yield traits, udder health, and fatty acids of Walloon Holstein 
cows. J. Dairy Sci. 98:4956-4968. https://doi.org/10.3168/jds.2014 $-9148$.

Hamzaoui, S., A. A. K. Salama, E. Albanell, X. Such, and G. Caja. 2013. Physiological responses and lactational performances of late lactating dairy goats under heat stress conditions. J. Dairy Sci. 96:6355-6365. https://doi.org/10.3168/jds.2013-6665.

Han, Z. Y., T. Mu, and Z. Yang. 2015. Methionine protects against hyperthermia-induced cell injury in cultured bovine mammary epithelial cells. Cell Stress Chaperones 20:109-120. https://doi.org/ 10.1007/s12192-014-0530-7.

Hermeking, H. 2010. The miR-34 family in cancer and apoptosis. Cell Death Differ. 17:193-199. https://doi.org/10.1038/cdd.2009.56.

Hu, Y., Q. Zhu, and L. Tang. 2014. MiR-99a antitumor activity in human breast cancer cells through targeting of mTOR expression. PLoS One 9:e92099. https://doi.org/10.1371/journal.pone .0092099 .

Hyder, I., P. R. K. Reddy, J. Raju, P. Manjari, C. S. Prasad, K. A. Kumar, and V. Sejian. 2017. Alteration in rumen functions and diet digestibility during heat stress in sheep. Pages 235-265 in Sheep Production Adapting to Climate Change. V. Sejian, R. Bhatta, J. Gaughan, P. Malik, S. Naqvi, and R. Lal, ed. Springer, Singapore. https://doi.org/10.1007/978-981-10-4714-5_11.

Jena, M. K. 2017. MicroRNAs in the development and neoplasia of the mammary gland. F1000Res. 6:1018. https://doi.org/10.12688/ f1000research.12005.2.

Joshi, B. C., H. B. Joshi, R. E. McDowell, and D. P. Sadhu. 1968. Composition of skin secretions from three Indian breeds of cattle under thermal stress. J. Dairy Sci. 51:917-920. https://doi.org/10 .3168/jds.S0022-0302(68)87105-X

Kapila, N., A. Kishore, M. Sodhi, A. Sharma, A. K. Mohanty, P. Kumar, and M. Mukesh. 2013. Temporal changes in mRNA expression of heat shock protein genes in mammary epithelial cells of riverine buffalo in response to heat stress in vitro. Int. J. Anim. Biotechnol. 3:5-9.

Kota, J., R. R. Chivukula, K. A. O'Donnell, E. A. Wentzel, C. L. Montgomery, H. W. Hwang, T. C. Chang, P. Vivekanandan, M. Torbenson, K. R. Clark, J. R. Mendell, and J. T. Mendell. 2009. Therapeutic microRNA delivery suppresses tumorigenesis in a murine liver cancer model. Cell 137:1005-1017. https://doi.org/10 .1016/j.cell.2009.04.021.

Lacasse, P., V. C. Farr, S. R. Davis, and C. G. Prosse. 1996. Local secretion of nitric oxide and the control of mammary blood flow. J. Dairy Sci. 79:1369-1374. https://doi.org/10.3168/jds.S0022 -0302(96)76494-9.

Lapierre, H., G. E. Lobley, L. Doepel, G. Raggio, H. Rulquin, and S. Lemosquet. 2012. Mammary metabolism of amino acids in dairy cows. J. Anim. Sci. 90:1708-1721. https://doi.org/10.2527/jas .2011-4645.

Lean, I. J., M. B. de Ondarza, C. J. Sniffen, J. E. P. Santos, and K. E. Griswold. 2018. Meta-analysis to predict the effects of metabolizable amino acids on dairy cattle performance. J. Dairy Sci. 101:340-364. https://doi.org/10.3168/jds.2016-12493.

Liu, H. Y., K. Zhao, M. M. Zhou, C. Wang, J. A. Ye, and J. X. Liu. 2010. Cytoprotection of vitamin $\mathrm{E}$ on hyperthermia-induced damage in bovine mammary epithelial cells. J. Therm. Biol. 35:250253. https://doi.org/10.1016/j.jtherbio.2010.05.010.

Loor, J. J., M. Bionaz, and J. K. Drackley. 2013. Systems physiology in dairy cattle: Nutritional genomics and beyond. Annu. Rev. Anim. Biosci. 1:365-392. https://doi.org/10.1146/annurev-animal -031412-103728.

Lough, D. S., D. L. Beede, and C. J. Wilcox. 1990. Effects of feed intake and thermal stress on mammary blood flow and other physiological measurements in lactating dairy cows. J. Dairy Sci. 73:325-332. https://doi.org/10.3168/jds.S0022-0302(90)78677-8.

Lu, L. M., Q. Z. Li, J. G. Huang, and X. J. Gao. 2012. Proteomic and functional analyses reveal MAPK1 regulates milk protein synthesis. Molecules 18:263-275. https://doi.org/10.3390/ molecules18010263.

Ma, L., and B. A. Corl. 2012. Transcriptional regulation of lipid synthesis in bovine mammary epithelial cells by sterol regulatory ele- ment binding protein 1. J. Dairy Sci. 95:3743-3755. https://doi .org/10.3168/jds.2011-5083.

Magenta, A., R. Ciarapica, and M. C. Capogrossi. 2017. The emerging role of miR-200 family in cardiovascular diseases. Circ. Res. 120:1399-1402. https://doi.org/10.1161/CIRCRESAHA.116 .310274 .

Mu, T., G. H. Kong, Z. Y. Han, and H. X. Li. 2014. Cytoprotection of methionine on hyperthermia-induced damage in bovine mammary epithelial cells. Cell Biol. Int. 38:971-976. https://doi.org/ 10.1002/cbin. 10271.

Nagaoka, K., H. Zhang, G. Watanabe, and K. Taya. 2013. Epithelial cell differentiation regulated by microRNA-200a in mammary glands. PLoS One 8:e65127. https://doi.org/10.1371/journal.pone .0065127

Nan, X., D. Bu, X. Li, J. Wang, H. Wei, H. Hu, L. Zhou, and J. J. Loor. 2014. Ratio of lysine to methionine alters expression of genes involved in milk protein transcription and translation and mTOR phosphorylation in bovine mammary cells. Physiol. Genomics 46:268-275. https://doi.org/10.1152/physiolgenomics.00119.2013.

O'Quinn, P. R., D. Knabe, and G. Wu. 2002. Arginine catabolism in lactating porcine mammary tissue. J. Anim. Sci. 80:467-474.

Osorio, J. S., E. Trevisi, P. Ji, J. K. Drackley, D. Luchini, G. Bertoni, and J. J. Loor. 2014. Biomarkers of inflammation, metabolism, and oxidative stress in blood, liver, and milk reveal a better immunometabolic status in peripartal cows supplemented with Smartamine M or MetaSmart. J. Dairy Sci. 97:7437-7450. https://doi .org/10.3168/jds.2013-7679.

Peterson, D. G., E. Matitashvili, and D. E. Bauman. 2004. The inhibitory effect of trans-10,cis-12 CLA on lipid synthesis in bovine mammary epithelial cells involves reduced proteolytic activation of the transcription factor SREBP-1. J. Nutr. 134:2523-2527.

Phua, Y. W., A. Nguyen, D. L. Roden, B. Elsworth, N. Deng, I. Nikolic, J. Yang, A. Mcfarland, R. Russell, W. Kaplan, M. J. Cowley, R. Nair, E. Zotenko, S. O'Toole, S. Tan, D. E. James, S. J. Clark, H. Kouros-Mehr, and A. Swarbrick. 2015. MicroRNA profiling of the pubertal mouse mammary gland identifies miR-184 as a candidate breast tumour suppressor gene. Breast Cancer Res. 17:83. https:/ /doi.org/10.1186/s13058-015-0593-0.

Pirkkala, L., P. Nykanen, and L. Sistonen. 2001. Roles of the heat shock transcription factors in regulation of the heat shock response and beyond. FASEB J. 15:1118-1131.

Reddi, S., N. Kumar, R. Vij, S. B. Mada, S. Kapila, and R. Kapila. 2016. Akt drives buffalo casein-derived novel peptide-mediated osteoblast differentiation. J. Nutr. Biochem. 38:134-144. https://doi .org/10.1016/j.jnutbio.2016.08.003.

Salama, A. A. K., G. Caja, S. Hamzaoui, B. Badaoui, A. Castro-Costa, D. E. Façanha, M. M. Guilhermino, and R. Bozzi. 2014. Different levels of response to heat stress in dairy goats. Small Rumin. Res. 121:73-79. https://doi.org/10.1016/j.smallrumres.2013.11.021.

Salama, A. A. K., G. Caja, S. Hamzaoui, X. Such, E. Albanell, B. Badaoui, and J. J. Loor. 2016. Thermal stress in ruminants: Responses and strategies for alleviation. Pages 11-36 in Animal Welfare in Extensive Production Systems. J. J. Villalba, ed. 5M, Sheffield, UK.

Shi, H. B., J. Luo, D. W. Yao, J. J. Zhu, H. F. Xu, H. P. Shi, and J. J. Loor. 2013. Peroxisome proliferator-activated receptor- $\gamma$ stimulates the synthesis of monounsaturated fatty acids in dairy goat mammary epithelial cells via the control of stearoyl-coenzyme A desaturase. J. Dairy Sci. 96:7844-7853. https://doi.org/10.3168/ jds.2013-7105.

Smith, L., E. W. Baxter, P. A. Chambers, C. A. Green, A. M. Hanby, T. A. Hughes, C. E. Nash, R. A. Millican-Slater, L. F. Stead, E. T. Verghese, and V. Speirs. 2015. Down-regulation of miR92 in breast epithelial cells and in normal but not tumour fibroblasts contributes to breast carcinogenesis. PLoS One 10:e0139698. https://doi.org/10.1371/journal.pone.0139698.

Sonna, L. A., S. L. Gaffin, R. E. Pratt, M. L. Cullivan, K. C. Angel, and C. M. Lilly. 2002. Effect of acute heat shock on gene expression by human peripheral blood mononuclear cells. J. Appl. Physiol. 92:2208-2220. https://doi.org/10.1152/japplphysiol.01002.2001. 
Tang, K. Q., Y. N. Wang, L. S. Zan, and W. C. Yang. 2017. miR27a controls triacylglycerol synthesis in bovine mammary epithelial cells by targeting peroxisome proliferator-activated receptor gamma. J. Dairy Sci. 100:4102-4112. https://doi.org/10.3168/jds .2016-12264.

Wang, D., G. Liang, B. Wang, H. Sun, J. Liu, and L. L. Guan. 2016a. Systematic microRNAome profiling reveals the roles of microRNAs in milk protein metabolism and quality: Insights on low-quality forage utilization. Sci. Rep. 6:21194. https://doi.org/10.1038/ srep21194.

Wang, J. X., Q. Zhang, S. Pei, and B. Yang. 2016b. Effect and mechanism of miR-34a on proliferation, apoptosis and invasion of laryngeal carcinoma cells. Asian Pac. J. Trop. Med. 9:494-498. https:/ /doi.org/10.1016/j.apjtm.2016.03.018.

Wang, M., B. Xu, H. Wang, D. Bu, J. Wang, and J. Loor. 2014. Effects of arginine concentration on the in vitro expression of casein and mTOR pathway related genes in mammary epithelial cells from dairy cattle. PLoS One 9:e95985. https://doi.org/10.1371/journal .pone.0095985.
Wang, M. Z., L. Y. Ding, C. Wang, L. M. Chen, J. J. Loor, and H. R. Wang. 2017. Arginase inhibition reduces the synthesis of casein in bovine mammary epithelial cells. J. Dairy Sci. 100:4128-4133. https://doi.org/10.3168/jds.2016-11823.

Wu, G., F. W. Bazer, T. A. Davis, S. W. Kim, P. Li, J. M. Rhoads, M. C. Satterfield, S. B. Smith, T. E. Spencer, and Y. Yin. 2009. Arginine metabolism and nutrition in growth, health and disease. Amino Acids 37:153-168. https://doi.org/10.1007/s00726-008-0210-y.

Zhang, C., Y. Zhao, Y. Wang, H. Wu, X. Fang, and H. Chen. 2014 Deep RNA sequencing reveals that microRNAs play a key role in lactation in rats. J. Nutr. 144:1142-1149. https://doi.org/10.3945/ jn.114.192575.

Zhou, Z., M. Vailati-Riboni, E. Trevisi, J. K. Drackley, D. N. Luchini, and J. J. Loor. 2016. Better postpartal performance in dairy cows supplemented with rumen-protected methionine compared with choline during the peripartal period. J. Dairy Sci. 99:8716-8732. https://doi.org/10.3168/jds.2015-10525. 